\section{Comment on "Mental health: why it still matters in the midst of a pandemic"}

Braz J Psychiatry. 2020 Jul-Aug;42(4):451 doi:10.1590/1516-4446-2020-1042
Jairo M. Gonzalez-Diaz, ${ }^{1,2}$ iD Lina Lozano-Lesmes, ${ }^{1,3}$ iD Adalberto Campo-Arias ${ }^{4}$ iD

${ }^{1}$ Centro Rosarista de Salud Mental (CERSAME), Escuela de Medicina y Ciencias de la Salud, Universidad del Rosario, Bogotá, Colombia. ${ }^{2}$ Clínica Nuestra Señora de la Paz, Bogotá, Colombia. ${ }^{3}$ Facultad de Ciencias de la Salud, Universidad del Tolima, Ibague, Colombia. ${ }^{4}$ Programa de Medicina, Facultad de Ciencias de la Salud, Universidad del Magdalena, Santa Marta, Colombia.

Submitted Apr 17 2020, accepted Apr 23 2020, Epub May 202020.

\section{Disclosure}

The authors report no conflicts of interest.

After the World Health Organization declared COVID-19 disease a pandemic, the number of confirmed cases has progressively increased to more than $1,600,000$, including 95,000 deaths, which has led to the implementation of quarantine and isolation strategies worldwide. However, approaches highly focused on COVID-19 infection control may tend to ignore the psychosocial consequences of the outbreak. As da Silva et al. recently stated, the stress experienced by patients, healthcare personnel and communities could increase the possibility of anxiety, depressive, and stress-related disorders, which could add an underestimated additional risk during the epidemic. ${ }^{1}$

However, we think that some Latin American countries might face particular challenges. As the COVID-19 epidemic advances, our fragile health systems already face a high internal (regional) migration, an increase in measles cases, intense transmission of dengue and recent outbreaks of zika and chikungunya. Unlike temperate zones, the co-circulation of these viruses in tropical countries could affect diagnostic capacity and worsen the epidemiological situation. In areas with adverse geographical and sanitary conditions, the risks are further increased. For example, some remote areas of Colombia have fewer than 0.5 hospital beds per 1,000 inhabitants, much less than the national average of neighboring countries. These areas are inhabited by approximately nine million victims of a 50-plus year armed conflict. The Colombian National Mental Health Survey revealed that people who resided near armed conflict events had a higher prevalence of mental problems and disorders. ${ }^{2}$ Notably, self-declared Amerindians also had higher rates of poverty, displacement due to violence, and mental disorders associated with acculturation. ${ }^{3}$

During the pandemic, numerous successful interventions involving technological tools have been reported around the globe. ${ }^{4}$ However, the wide urban/rural gap and an internet access rate around $50 \%$ in many countries could be a barrier to web-based mental health services. Therefore, locally adapted responses to the COVID-19 pandemic must consider their impact on the mental health of vulnerable communities, emphasizing the strengthening of primary care and the role of social leaders. Critical situations like this pandemic will make the longstanding social inequities of our continent more evident. Amartya Sen aptly said that the fundamental requirement for enjoying better community mental health implies establishing high degrees of justice, equality, and social capital. $^{5}$
How to cite this article: Gonzalez-Diaz JM, LozanoLesmes L, Campo-Arias A. Comment on "Mental health: why it still matters in the midst of a pandemic." Braz $\mathrm{J}$ Psychiatry. 2020;42:451. http://dx.doi.org/10.1590/15164446-2020-1042

\section{References}

1 da Silva AG, Miranda DM, Diaz AP, Teles AL, Malloy-Diniz LF, Palha AP. Mental health: why it still matters in the midst of a pandemic. Braz J Psychiatry. 2020;42:229-31.

2 Gómez-Restrepo C, Tamayo-Martínez N, Buitrago G, GuarnizoHerreño CC, Garzón-Orjuela N, Eslava-Schmalbach J, et al. Violencia por conflicto armado y prevalencias de trastornos del afecto, ansiedad y problemas mentales en la población adulta colombiana. Rev Colomb Psiquiatr. 2016;45(Suppl 1):147-53.

3 Gómez-Restrepo C, Rincón CJ, Urrego-Mendoza Z. Salud mental, sufrimiento emocional, problemas y trastornos mentales de indígenas colombianos. Datos de la Encuesta Nacional de Salud Mental 2015. Rev Colomb Psiquiatr. 2016;45(Suppl 1):119-26.

4 Ransing R, Frances AN, Pereira-Sanchez V, Ramalho R, Orsolini L, Teixeira ALS, et al. Early career psychiatrists' perspectives on the mental health impact and care of the COVID-19 pandemic across the world. Asian J Psychiatry. 2020;51:102085.

5 Sen A. [Why should there be equity in health?] Rev Panam Salud Publica. 2002;11:302-9.

\section{Supporting people with severe mental health conditions during the COVID-19 pandemic: considerations for low- and middle-income countries using telehealth case management}

Braz J Psychiatry. 2020 Jul-Aug;42(4):451-452 doi:10.1590/1516-4446-2020-1078

\section{(cc) BY-NC}

The coronavirus disease 2019 (COVID-19) pandemic is a global challenge to humankind. Such disasters might 